\title{
Growth and yield of transplanted rice as affected by different cultivars and weed management practices
}

\author{
Sunil Mandi ${ }^{*}$, Eajaz Ahmad Dar ${ }^{2}$, Ashim Datta ${ }^{3}$, Ram Pratap Singh ${ }^{4}$, Manoj Kumar \\ Singh $^{4}$ \\ ${ }^{1}$ Central Tobacco Research Institute, Research Station, Dinhata, Cooch Behar-736135 (West Bengal), INDIA \\ ${ }^{2}$ Department of Agronomy, PAU- Ludhiana-141004 (Punjab), INDIA \\ ${ }^{3}$ Division of Soil and Crop Management, Central Soil Salinity Research Institute, Karnal-132001 (Haryana), INDIA \\ ${ }^{4}$ Department of Agronomy, Institute of Agricultural Sciences, Banaras Hindu University, Varanasi-221005 (U.P.) INDIA \\ *Corresponding author. E-mail: mandi.sunil@gmail.com
}

Received: December 15, 2015; Revised received: June 17, 2016; Accepted: August 05, 2016

Abstract: An experiment was conducted to study the competitive ability of rice cultivars in different weed management practices in transplanted rice. Five cultivars viz. BPT-5204, Malviya 36, HUBR2-1, Swarna and Adamchini were tested for three weed management practices viz. Hand weeding, Bispyribac-sodium@25g ha- ${ }^{1}$ and Weedy check. Among the different cultivars tested, the Swarna proved to be the best selection in producing higher grain $\left(4.6 \mathrm{t} \mathrm{ha}^{-1}\right)$ and straw yield $\left(5 \mathrm{tha}^{-1}\right)$ as well as harvest index $(44.4 \%)$ due to more no. of tillers hill ${ }^{-1}$, dry matter accumulation, no. of panicles hill ${ }^{-1}$, no. of grains/panicle and test weight $(20.3 \mathrm{~g})$. The grain and straw yield in Swarna were 130 and $43 \%$ higher than the lowest yielding cultivar Adamchini respectively. The best weed control was achieved by hand weeding thrice at 25, 55 and 85 DAT. The grain yield was 58 and $27 \%$ higher through hand weeding than that of weedy check and Bispyribac-sodium applied treatment, respectively. To examine the performance of different rice cultivars in terms of growth and yield potential, evaluation of these cultivars is necessary with different weed management practices. Therefore, release of best weed suppressive rice cultivars for the farmers is important for improving the productivity as well as reduced cost of production for feeding the ever growing population of the country in the year to come.

Keywords: Cultivar, Paddy, Weed management, Yield

\section{INTRODUCTION}

Rice (Oryza sativa L.) is the leading cereal of the world and more than half of the human race depends on rice for their daily sustenance (Chauhan and Johnson, 2011). In India, during 2012-13 rice was grown on an area of $43.65 \mathrm{~m}$ ha with a production of $104 \mathrm{mt}$ (GOI, 2013). In Asia more than $90 \%$ of people consume rice, where it is a staple food for majority of the population, including 560 million hungry people in this region (IRRI, 2013). World's rice demand is projected to increase by $25 \%$ from 2001 to 2025 , therefore, it is a great challenge to meet the ever increasing rice demand in a sustainable way with shrinking natural resources. Weeds are as old as agriculture, and from the very beginning farmers realized the interference of weeds with crop productivity which led to the coevolution of agro-ecosystems and weed management (Ghersa et al., 1994). Weeds are the greatest yieldlimiting constraint to rice (WARDA, 1996). Ramzan (2003) reported yield reduction up to 48,53 and $74 \%$ in transplanted, direct seeded flooded and direct seeded aerobic rice, respectively. However, different weed control options are available for rice. Physical control methods are eco-friendly but tedious and labourintensive. Other problems include delayed weeding due to unavailability of labour, damage to the rice seedlings and mistaken removal of rice seedlings. Chemical control, on the contrary, is the most effective, economic and practical way of weed management. Bispyribac-sodium \{[Sodium 2,6-bis [(4, 6dimethoxypyrimidin-2-yl) oxy] benzoate $\}$ is a new post emergence herbicide for the control of a wide range of weeds infesting rice. Herbicide application from the third/ fourth unfolded leaf stage up to tillering stage provides effective weed control and is not phytotoxic to rice, hence ensuring an increase in yield. But, intensive use of herbicides may result in development of resistant weed biotypes, crop phytotoxicity and public health hazard. The other option left is cultural weed control through adoption of different competitive cultivars (Zhao et al., 2006) among many others (tillage, seeding density, water management, fertilizer management, seed invigoration and mulching).

Cultivation of dwarf and semi-dwarf varieties with input responsive morphology and canopy development pattern than the traditional tall varieties, has accentuated the problem of weed control. In tall varieties, the 
canopy closure takes place faster than in dwarf varieties because of their long and droopy leaves and quick initial vigor, thus smothering the weed growth much effectively than the dwarf varieties. Inadequate land preparation and increased fertilizer use for dwarf varieties has further added to this misery. Resistance to herbicide and the lack of viable control options have led to an interest in increasing the role of crop competition as a weed management tool in transplanted rice. Weed suppressive rice cultivars have therefore been suggested an effective tool to improve weed control and reduce the reliance of growers on herbicides (Mahajan et al., 2013; Benaragama et al., 2014; Chaudhari et al., 2014). Therefore, an attempt has been made to study the competitive ability of rice cultivars under different weed management practices under transplanted conditions.

\section{MATERIALS AND METHODS}

Field studies were conducted during the kharif season of 2009 at the Agricultural Research farm, Institute of Agricultural Sciences, Banaras Hindu University, Varanasi, U.P. situated in the south-eastern part of Varanasi city at an altitude of 128.9 meters above mean sea level, $25^{\circ} 18^{\prime} \mathrm{N}$ latitude and $80^{\circ} 36^{\prime} \mathrm{E}$ longitude. The study area falls under subtropical climate. The normal period of occurrence of monsoon is third week of June and remains effective up to September. The mean annual rainfall of the region is about $1100 \mathrm{~mm}$. The temperature begins to rise from the middle of February and reaches to its maximum by May or the middle of June, whereas December is the coldest period of the year. The weather conditions during the growing season are shown in Table 1. The total rain fall received during the crop season in 2009 was $461.1 \mathrm{~mm}$, the maximum rain fall $(106.0 \mathrm{~mm})$ was recorded in the first week of September. The maximum $\left(35^{\circ} \mathrm{C}\right)$ and the minimum $\left(11.6^{\circ} \mathrm{C}\right)$ temperature were recorded in first week of August and third week of November, respectively. The maximum relative humidity range was from 87 to $70 \%$ and minimum from 81 to $30 \%$, whereas the average sunshine recorded during the crop season was $6.32 \mathrm{hrs}$. The soil of the experimental field belongs to typical Indo-Gangetic alluvium (Entisols) with a sandy clay loam texture. Chemical analysis of the soil (top $15 \mathrm{~cm}$ ) showed a neutral $\mathrm{pH}(7.5), 0.40 \%$ organic carbon, $237 \mathrm{~kg} \mathrm{ha}^{-1}$ permanganate extractable nitrogen, $16.9 \mathrm{~kg} \mathrm{ha}^{-1}$ Olsen's (0.5 $\mathrm{M} \mathrm{NaHCO}_{3}$ extractable) phosphorus and $140 \mathrm{~kg} \mathrm{ha}^{-1}$ exchangeable potassium.

The experiment was laid out in to split plot design with five rice cultivars viz. BPT-5204, Malaviya 36, HUBR2-1, Swarna and Adamchini as main plot treatments and three methods of weed control viz. Control (weedy), Bispyribac Sodium $\left(25 \mathrm{~g} \mathrm{ha}^{-1}\right)$ and weed free as sub plot treatments. The seedlings (25 days old) were transplanted at 2-3 seedlings per hill at a spacing of $20 \mathrm{~cm} \mathrm{x} 15 \mathrm{~cm}$. Half dose of $\mathrm{N}\left(60 \mathrm{~kg} \mathrm{ha}^{-1}\right)$ along with $60 \mathrm{~kg} \mathrm{P}_{2} \mathrm{O}_{5} \mathrm{ha}^{-1}$ and $60 \mathrm{~kg} \mathrm{~K}_{2} \mathrm{O} \mathrm{ha}^{-1}$ was applied as basal dose, whereas the remaining dose of Nitrogen $\left(60 \mathrm{~kg} \mathrm{ha}^{-1}\right)$ was top dressed in two equal splits at tillering and panicle initiation stage. The herbicide was applied as post-emergence at 25 days after transplanting (DAT), with hand sprayer after preparing the stock solution of desired concentration per plot by using 800 liters of water ha ${ }^{-1}$. The hand weeding was done thrice (20, 40 and 60 DAT) in weed free plots. Five plants were tagged randomly from each plot for recording of growth and yield attributes. Statistical analysis of the recorded data was done using the standard procedures of analysis of variance in split plot design with the help of statistical software IRRISTAT (IRRI, 1999) and statistical mean differences were found by Fisher's protected least significant difference test at $\mathrm{P}<0.05$.

\section{RESULTS AND DISCUSSION}

Plant height: The plant height $(92.3 \mathrm{~cm})$ of cultivar Malviya 36 at 60 DAT was significantly higher than BPT-5204 and Swarna, but at par with other cultivars. However, at 90 DAT and at harvest, cultivar Adamchini produced significantly $(\mathrm{P}=0.05)$ taller plants than other cultivars except Malviya 36 (Table 1). At harvest, plant height of $100.3 \mathrm{~cm}$ in Adamchini was $18.5 \%$ higher than that of the Swarna, which produced the shortest plants. Among the weed management practices, hand weeding resulted in significantly $(\mathrm{P}=0.05)$ higher plant height at all stages of crop growth than Bispyribac-Sodium due to better control of weeds. The plant height in hand weeded treatment was $11.7,18.9$ and $18.4 \%$ higher than weedy check and 5.7, 5.7 and $12.6 \%$ higher than BispyribacSodium applied treatment at 60, 90 DAT and at harvest, respectively. On the other side, plant height in Bispyribac-Sodium applied treatment was 5.7, 12.5 and $5.1 \%$ higher than weedy check plots at 60,90 DAT and at harvest, respectively due to severe cropweed competition under weedy check. Mennan et al., (2012) recorded weed E. Crus-Galli interference reduced height whereas weed free field recorded highest yield. So, plant height were critical trait related to competitiveness with weeds.

Number of tillers/ hill: From the data on number of tillers/ hill (Table 1), it can be revealed that the tiller production ability varies with cultivar as well as the growth stage. The tiller production increases upto a certain stage and starts declining towards the reproductive stages of the crop. Similar trend has been found in our findings also where the number of tillers/ hill increased up to 90 DAT and then declined towards maturity. Regarding cultivar differences, number of tillers/ hill was significantly $(\mathrm{P}=0.05)$ higher in the cultivar Swarna than other cultivars at all the stages of crop growth. The cultivar BPT-5204 and Malviya 36 were found to be statistically at par; however the cultivar HUBR2-1 produced lowest number of tillers (Table 1). 
Sunil Mandi et al. / J. Appl. \& Nat. Sci. 8 (3): 1462 - 1466 (2016)

Table 1. Effect of cultivars and weed management practices on growth attributes of transplanted rice.

\begin{tabular}{|c|c|c|c|c|c|c|c|c|c|}
\hline \multirow[t]{2}{*}{ Treatment } & \multicolumn{3}{|c|}{ Plant height (cm) } & \multicolumn{3}{|c|}{ No. of Tiller shill $^{-1}$} & \multicolumn{3}{|c|}{ Shoot dry wt. $\left(\mathrm{g} \mathrm{m}^{-2}\right)$} \\
\hline & $\begin{array}{c}60 \\
\text { DAT } \\
\end{array}$ & $\begin{array}{c}90 \\
\text { DAT }\end{array}$ & Harvest & 60 DAT & 90 DAT & Harvest & $60 \mathrm{DAT}$ & 90 DAT & Harvest \\
\hline \multicolumn{10}{|l|}{ Cultivar } \\
\hline BPT-5204 & 64.5 & 78.7 & 81.9 & 7.5 & 9.6 & 8.1 & 157.7 & 179.5 & 190.9 \\
\hline Malviya 36 & 92.3 & 93.9 & 95.6 & 7.9 & 9.6 & 8.2 & 277.7 & 292.6 & 305.8 \\
\hline HUBR2-1 & 82.1 & 87.2 & 88.9 & 6.8 & 7.5 & 6.4 & 233.4 & 252.9 & 260.5 \\
\hline Swarna & 72.6 & 82.5 & 84.6 & 8.6 & 11.0 & 9.8 & 279.4 & 303.2 & 318.8 \\
\hline Adamchini & 81.1 & 95.3 & 100.3 & 6.7 & 8.7 & 7.4 & 180.9 & 191.7 & 200.5 \\
\hline $\mathrm{CD}(\mathrm{P}=0.05)$ & 15.7 & 3.6 & 6.9 & 1.2 & 1.4 & 1.2 & 22.3 & 15.8 & 16.7 \\
\hline \multicolumn{10}{|c|}{ Weed management practice } \\
\hline $\begin{array}{l}\text { Hand weeding } \\
\text { Bispyribac- }\end{array}$ & 82.9 & 94.3 & 99.1 & 9.1 & 11.2 & 10.1 & 276.6 & 292.3 & 308.4 \\
\hline sodium@25g/ha & 78.4 & 89.2 & 88.0 & 7.1 & 9.0 & 7.5 & 226.9 & 249.0 & 260.6 \\
\hline Weedy check & 74.2 & 79.3 & 83.7 & 6.3 & 7.7 & 6.4 & 174.0 & 190.5 & 196.9 \\
\hline $\mathrm{CD}(\mathrm{P}=0.05)$ & 2.72 & 2.05 & 2.4 & 0.80 & 0.51 & 0.6 & 17.77 & 12.48 & 8.5 \\
\hline
\end{tabular}

Table 2. Effect of cultivars and weed management practices on yield attributes and yield of transplanted rice.

\begin{tabular}{ccccccc}
\hline Treatment & $\begin{array}{c}\text { No. of pani- } \\
\text { cles/ hill }\end{array}$ & $\begin{array}{c}\text { No. of grains/ } \\
\text { panicle }\end{array}$ & $\begin{array}{c}\text { Test weight } \\
(\mathbf{g})\end{array}$ & $\begin{array}{c}\text { Grain yield } \\
(\mathbf{t} / \mathbf{h a})\end{array}$ & $\begin{array}{c}\text { Straw yield } \\
(\mathbf{t} / \mathbf{h a})\end{array}$ & $\begin{array}{c}\text { Harvest Index } \\
(\%)\end{array}$ \\
\hline Cultivar & & & & & & \\
BPT-5204 & 7.9 & 137.6 & 11.3 & 2.7 & 3.7 & 41.6 \\
Malviya 36 & 8.2 & 125.3 & 19.8 & 3.6 & 4.6 & 44.2 \\
HUBR2-1 & 6.5 & 88.4 & 18.5 & 2.5 & 4.3 & 36.4 \\
Swarna & 8.7 & 142.8 & 20.3 & 4.6 & 5.0 & 44.4 \\
Adamchini & 7.5 & 109.9 & 9.6 & 2.0 & 3.5 & 33.7 \\
CD(P=0.05) & 0.5 & 3.8 & 0.7 & 0.1 & 0.2 & 0.8 \\
Weed management practice & 9.3 & 130.9 & 18.3 & 3.8 & 4.9 & 43.4 \\
Hand weeding & & 121.5 & 15.2 & 3.0 & 4.2 & 40.1 \\
Bispyribac- & 7.3 & 110.1 & 14.2 & 2.4 & 3.6 & 36.8 \\
sodium@ 25g/ha & 6.6 & 1.8 & 0.4 & 0.1 & 0.1 & 1.1 \\
Weedy check & 0.4 & & & & \\
CD(P=0.05) & & & & & & \\
\hline
\end{tabular}

The tiller production ability of Swarna was 26, 47 and $53 \%$ higher than cultivar HUBR2-1 at the respective growth stages. This might be due to the differences in genetic constitution of the cultivars. The weed management practices significantly affected the tiller production ability. Hand weeding recorded significantly $(\mathrm{P}=0.05)$ more number of tillers than Bispyribac - sodium and weedy check. Bispyribac - sodium treatment was not as effective as hand weeding thrice, but was superior to weedy check, in respect of tillers production by crop. The number of tillers was 28,24 and $35 \%$ higher than Bispyribac - sodium and 44, 45 and 58\% higher than weedy check at the respective growth stages. Similarly Bispyribac - sodium has been able to produce 13, 17 and $17 \%$ more tillers than weedy check at 60, $90 \mathrm{DAT}$ and at harvest, respectively. Application of Bispyribac-sodium as post emergence @ 25 $\mathrm{g} \mathrm{ha}^{-1}$ in transplanted rice produced more tillers, panicles, grain yield and also economical (Veeraputhiram and Balasubramanian, 2013).

Dry matter production: Dry matter production varied significantly among rice cultivars. Cultivar Swarna was significantly superior to rest of the cultivars and recorded maximum dry matter accumulation (DMA) of
$318.79 \mathrm{~g} \mathrm{~m}^{-2}$ at all the stages but was at par with cultivar Malviya 36 (Table 1). The cultivar BPT-5204 and Adamchini showed lower DMA than all other cultivars and was 54, 58 and 59\% less than the highest DMA cultivar Swarna at 60, 90 DAT and at harvest, respectively. Herbicide treated field recorded higher plant height, number of shoot per hill, Leaf area index and dry matter accumulation resulting highest grain and straw yield than weedy check (Pandey et al., 2013). The hand weeding thrice was significantly $(\mathrm{P}=0.05)$ superior to rest of the weed control treatments and recorded maximum dry matter accumulation which was 22, 17 and $18 \%$ higher than the herbicide treatment and 59, 53 and 57\% higher than the weedy check at 60 , 90 DAT and at harvest, respectively. However, the herbicidal treatment showed significant superiority over weedy check in promoting the dry matter accumulation and was 30, 31 and 32\% higher than weedy check at the respective crop growth stages. The rice plant characteristics associated with weed competitiveness are plant height, together with high canopy cover at the early stage of growth, high tiller density, droopy leaves, high biomass accumulation at the early crop stage, high leaf area index and high specific leaf area 
during vegetative growth, rapid canopy ground cover, and early vigour (Chauhan et al., 2014).

\section{No. of panicles/hill, no. of grains/panicle and test} weight: The yield attributing characters like no. of panicles/hill, no. of grains/panicle and test weight were found to be highest in the cultivar Swarna, while as the HUBR2-1 cultivar showed the lowest no. of panicles/ hill (6.5) and no. of grains/panicle (88.4) but test weight (9.6g) was lowest for Adamchini cultivar, which was less than half of the test weight of cultivar Swarna (20.3g) (Table 1). Among the weed management practices, hand weeding proved to be the best practice in improving the no. of panicles/hill, no. of grains/panicle and test weight. The reduction in no. of panicles/hill, no. of grains/panicle and test weight in weedy check was 41, 19 and $29 \%$ than that of hand weeding and 11, 10 and $7 \%$ than that of Bispyribacsodium applied treatments. Also shifting from herbicide to hand weeding increased the no. of panicles/hill, no. of grains/panicle and test weight by 27,8 and $20 \%$ respectively. According to Singh et al. (2014) highest tillers $\mathrm{m}^{-2}$ and grain yield was obtained with weed free conditions which was at par with the application of bispyribac-sodium @ 20-25 $\mathrm{g} \mathrm{ha}^{-1}$ at 1-3 leaf stage in rice. However, the highest weed control efficiency and maximum grain yield were recorded under two hand weeding which was at par with post emergence application of bispyribac-soduim @ $25 \mathrm{~g} \mathrm{ha}^{-1}$ supplemented with hand weeding at 45 DAT (Parthipan and Ravi, 2016).

Grain and straw yield: The rice grain yield is a product of number of panicle per unit area, number of grains/ panicle and 1000 grain weight. Swarna produced highest number of panicles/ hill, grains/ panicle and test weight, which ultimately resulted in higher yield. The grain and straw yield in Swarna were respectively 130 and $43 \%$ higher than the lowest yielding cultivar Adamchini (Table 1).Variation in grain yield and yield attributing characters among cultivars are supported by the findings of Ekeleme et al. (2009). Highest straw yield was produced by cultivar Swarna due to highest number of tillers and more dry matter production. Minimum straw yield was produced by BPT-5204. The maximum harvest index was recorded for cultivar Swarna, whereas, lowest was recorded for cultivar Adamchini. Harvest index is the ratio of economic yield to biological yield, expressed as percentage. The greater the differences between economic yield and biological yield, the lower will be harvest index and vice-versa. Rice cultivars with tall plant height due to its early and high canopy cover tend higher weed competitiveness but it has low yield and lodging problem. Semi- dwarf cultivars also have the same ability to compete with weeds where these cultivars have higher yield potential than tall rice cultivars. Therefore, intermediate height with high yield may be a desirable trait (Fischer et al., 2001; Fukai, 2002). The results also indicated that hand weeding and Bispyri- bac- sodium weed control treatments resulted in significantly higher yield over weedy check. Higher grain yield under these treatments is due to better growth of crop in terms of higher dry matter accumulation in addition to low density and DMA of weeds. A weed free environment facilitated good crop growth, more number of tillers, grains/panicle and bolder seeds; hence higher grain yield (Mukherjee et al., 2008 and Chauhan et al., 2010).

\section{Conclusion}

Among the different cultivars tested, Swarna proved to be the best selection in producing higher grain $(4.6 \mathrm{t}$ ha $\left.{ }^{-1}\right)$ and straw yield $\left(5.0 \mathrm{t} \mathrm{ha}^{-1}\right)$ as well as harvest index (44.4) due to more no. of tillers/hill, dry matter accumulation, no. of panicles/hill (8.7), no. of grains/ panicle (142.8) and test weight $(20.3 \mathrm{~g})$. The best weed control was achieved by hand weeding thrice at 25, 55 and 85 DAT; however it is tedious and labour demanding and thus can be substituted and/or replaced by Bispyribac-sodium @ $25 \mathrm{~g} \mathrm{ha}^{-1}$ as post emergence.

\section{REFERENCES}

Benaragama, D., Rossnagel, B.G. and Shirtliffle, S.J. (2014). Breeding for Competitive and High-Yielding Crop Cultivars. Crop Sci. 54(3):1015-1025.

Chaudhari, P., Patel, A., Saxena, R.R. and Verulkar, S.B. (2014). Evaluation of the relative weed competiveness ability in upland rice cultivars. J. Progr. Agri. 5(2): 90-94.

Chauhan, B.S. and Johnson, D.E. (2010). Implications of narrow crop row spacing and delayed Echinochloa colona and Echinochloa crus-galli emergence for weed growth and crop yield loss in aerobic rice. Field Crops Res. 117(2-3):117-182.

Chauhan, B.S. and Johnson, D.E. (2011). Growth response of direct seeded rice to oxadiazon and bispyribacsodium in aerobic and saturated soils. Weed Sci. 59(1): 119-122.

Chauhan, B.S., Kumar,V. and Mahajan, G. (2014). Research needs for improving weed management in rice. Ind. J. Weed Sci. 46(1):1-3.

Ekeleme, F., Kamara, A.Y., Oikeh, S.O., Omoigui, L.O., Amaza, P., Abdoulaye, T. and Chikoye, D. (2009).Response of upland rice cultivars to weed competition in the savannas of West Africa. Crop Prot. 28 (1): $90-96$.

Fischer, A.K., Ramirez, H.V., Gibson, D.S. and Silveira, B.P.D. (2001). Competitiveness of semidwarf upland rice cultivars against palisadegrass (Brachiaria brizantha) and signalgrass (B. decumbens). Agron. J. 93(5): 967-973.

Fukai, S. (2002). Rice cultivar requirement for direct-seeding in rainfed lowlands. In: Direct seeding: research strategies and opportunities. (Eds. Pandey S, et al.) Proceedings of the International Workshop on Direct Seeding in Asian Rice Systems: Strategic Research Issues and Opportunities? pp 15-39.

Ghersa, C.M., Roushl, M.L., Radosevich, S.R. and Cordray, S.M. (1994). Coevolution of agroecosystems and weed management. Bio Sci. 4: 85-94. 
GOI (2013).Agricultural Statistics at a Glance.Ministry of Agriculture, Department of Agriculture and cooperation, Directorate of Economics and Statistics, Government of India, pp 37.

IRRI (1999). IRRISTAT for windows version 4.0. Biometrics unit, IRRI, Los Banos, Phillippines.

IRRI (2013). Rice today. http//www.irri.org/rice-today/trends -in-global-rice-consumption.

Mahajan, G. and Chauhan, B.S. (2013). The role of cultivars in managing weeds in dry seeded rice production system. Crop Prot. 49: 52-57.

Mennan, H., Naoujio, M., Sahin, M., Isik, D. and Alto, E.K. (2012). Competitiveness of Rice (Oryza Sativa L.) cultivars against Echinochloa Crus-Galli (L.) Beauv. in water seeded production system. Crop Prot. 41: 1-9.

Mukherjee, P.K., Sarkar, A. and Maity, S.K. (2008). Critical period of crop-weed competition in transplanted and wet-seeded kharif rice (Oryza sativa L.) under terai conditions. Ind. J. Weed Sci. 40(3\&4): 147-152.

Pandey, P.R. and Singh, G. (2013). Weed management in transplanted rice (Oryza Sativa L.). Annals of Plant
Prot. Sci. 21(1):160-162.

Parthipan, T. and Ravi, V. (2016). Productivity of transplanted rice as influence by weed control methods. Afri. J. Agri. Res. 11(6):1445-1449.

Ramzan, M. (2003). Evaluation of various planting methods in rice-wheat cropping systems, Punjab, Pakistan. Rice Crop Report ,2003-2004 pp 4-5.

Singh, R., Pal, R., Singh, T.P., Singh, A.P., Yadav, S. and Singh, J. (2014). Management of weeds in direct seeded rice by bispyribac-sodium. Ind. J. Weed Sci. 46(2):126128.

Veeraputhiram, R. and Balasubramanian, R. (2013). Evaluation of Bispyribac-sodium in Transplanted Rice. Ind. J. weed Sci. 45(1):12-15.

WARDA (West Africa Rice Development Association) 1996.Annual Report for 1995.West Africa Rice Development Association, Bouake, Cote d'Ivoire.

Zhao, D.L., Atlin, G.N., Bastiaans, L. and Spiertz, J.H.J. (2006). Developing selection protocols for weed competitiveness in aerobic rice. Field Crops Res. 97(2-3): 272-285. 